\author{
菱田公

\section{Combined Laser-Based Measurements for Dispersed Two-Phase Flows} \\ Koichi HISHIDA*2 \\ ${ }^{* 2}$ Department of System Design Engineering, Keio University, \\ 3-14-1 Hiyoshi, Kohoku-ku, Yokohama-shi, Kanagawa, 223-8522 Japan
}

-

\begin{abstract}
This paper presents mainly a review of experimental study on the turbulent structure of dispersed two-phase flow employing advanced laser techniques such as Shadow Doppler Velocimetry and Particle Image Velocimetry combined with Laser Induced Fluorescence. Shadow Doppler Velocimetry has been developed for particle sizing of arbitrary shaped particle, i.e. non-spherical particle. For the bubbly flow, combined shadow image and DPIV techniques allow us to acquire the detailed information of two-dimensional bubble motion and velocity vectors very close to the bubble. Microscale structures of turbulence associated with dispersed phase motion are certainly obtained by these Laser measurement techniques. Furthermore, PIV measurements in micro channel flow with sub-micron solid particles evaluated electroosmotic flow from particle motion in an applied electric field.
\end{abstract}

Key Words: Dispersed Flows, Gas-Solid, Gas-Liquid, Liquid-Solid Two-Phase Flows, Laser Techniques, Particle Image Velocimetry, Micro Scale

\section{1.はじめに}

連続媒体中に異相物質が分散する二相流では，運動 量, 物質およびエネルギーの移動が複雑に絡み合うた め，いまだ解明されていない部分が数多い.このよう な混相流動の本質を把握するためには流れの構造が本 質的に多重化される乱流の微細構造を実験的に明らか にすることが, より普遍的な混相乱流のモデル化には 必要不可欠である.

非接触法による測定という観点からは，レーザを用 いる光学的測定法が挙げられる.もちろん, 光学的な 測定は光路をさえぎる粒子の量が多くなると, 測定が 困難になるという弱点があるにせよ，場を乱さずに測 定ができるというこれまでになかった非接触法である ことから、レーザを用いる計測法は新しい知見を得る ための有力な方法の一つとなる. 代表的な方法にはレ ーザドップラー流速計 LDV (Laser Doppler Velocimetry) と粒子画像流速計 PIV (Particle Image Velocimetry)がある. LDVが 1964 年に Yeh-Cum-

\footnotetext{
* 原稿受付 2008 年 2 月 28 日.

${ }^{* 1}$ 正員, フェロー, 慶應義塾大学理工学部(乯223-8522 横浜市 港北区日吉 3-14-1).

E-mail : hishida@sd.keio.ac.jp
}

$\mathrm{mins}^{(1)}$ により発表されて四十余年, PIVは 1984 年に Adrian $^{(2)}$ により初めて発表され, 二十余年が過ぎよ うとしている.

1970 年代にはいって急速に進歩し, 性能が安定して きたレーザドップラー流速計(LDV)を二相流に適用 することが考えられ，多くの研究者によって測定が試 みられてきた.さらに, 光減衰に対応し得るドップラ 一位相法の手法の開発・改良が進み, より高度の情報 が入手できるようになってきている.

一方, 近年のディジタル技術の著しい進展によって, 点計測から面的な計測が可能になってきた。これらは Adrian $^{(3)}$ による面的な測定法のレビューにまとめら れている. 最近では熱流動場の多点同時計測を目的と して, ビデオ画像を利用した流速や温度, 濃度等の面 的計測手法に関する論文が数多く発表されており, 強 力な計測法として認められつつある。その中では流速 測定法として確立されてきており, 計測装置としての 製品化も進んでいる.しかし，高価な画像計測システ ム一式を購入したとしても, ハードウェアに依存した 多くの限界や細かいノウハウの不足によって, 必ずし も満足な結果をもたらすとはいいがたい. そこには実 験者が測定原理および計測システムの詳細を理解して いることはもちろんのこと, 独自に工夫した計測を行 
う必要がある.

著者の恩師 (前田昌信慶大名誉教授) は最近，これら の経緯について連載記事にまとめられておられるの で, 参考にしていただきたい(4).この展望では著者ら の研究室でこの 20 年あまりの間に自分自身で開発し, 単なる速度測定にとどまらず, 粒子径やその形状の測 定などを付加した複合計測システムについて展望する ことにする。

\section{2.レーザ流速計による二相流動計測}

レーザ流速計は図 1 に示すようにレーザ光を 2 本に 分け，1点に結ぶことにより，その交差部分を通過す る粒子の速度が測定できるＬDV に分散相の粒子径 を測定できる機能を加える方法を図 1 に示す.Mie の散乱理論に基づき散乱光強度を測定するもの, ドッ プラー信号の明りょう度(ビジビリティ)より測定する もの, 複数の受光素子間の位相を検出して粒径を測定 するものなどがある. 著者らもこれらの手法を開発
し, 二相流の流動の解析を行ってきた ${ }^{(5)(6)}$. 散乱光強 度法は散乱パラメータ $(=\pi d / \lambda, \lambda: レ ー サ ゙$ 光の波長 $)$ が約 5 以上では散乱光強度は粒径のほぼ二乗に比例す るので LDV の測定体積のほぼ中央を通過した粒子の 信号を検出すれば粒径と速度が同時に測定できる。そ の信号処理は，図 2 に示されるようなぺデスタル信号 にフィルタをかけ，おのおののドップラー信号の周波 数を計測すれば速度が求められる. 処理器としては, カウンタとトラッカタイプのものがよく用いられてき たが, 最近では, ディジタル信号処理技術の進展に伴 い, 自己相関法や FFT 法(7)による処理器が広く用い られている.これらは従来のカウンタタイプに比べ， イズに強いなどの特徴を有する.

二相流中での乱流構造を明らかにするには, 両相の 変動速度まで的確にとらえる必要がある。そのような 場合, 大径㧍よび小径粒子が弁別できる程度でも, 両 相の速度を正確にとらえられることのほうが重要であ る. 連続相に $1 \mu \mathrm{m}$ 程度のトレーサ粒子を混入してお

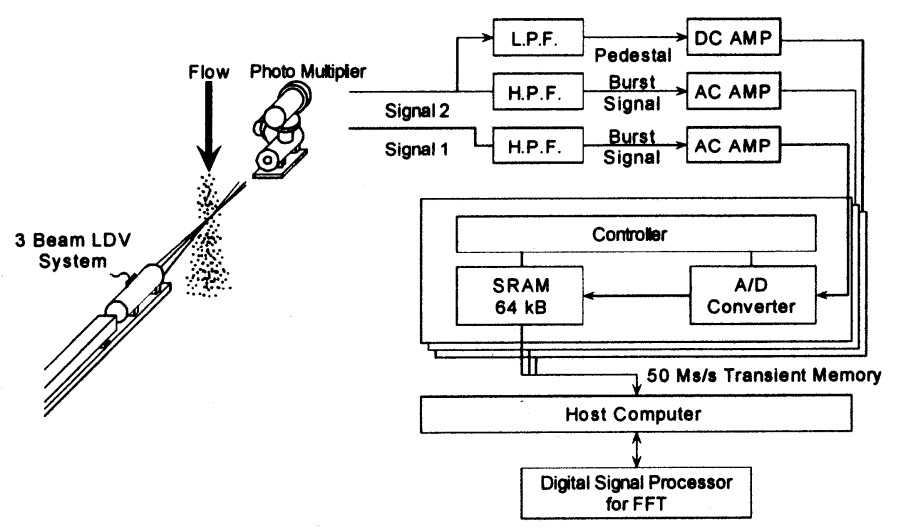

Fig. 1 Modified Laser Doppler Velocimetry with particle size discrimination

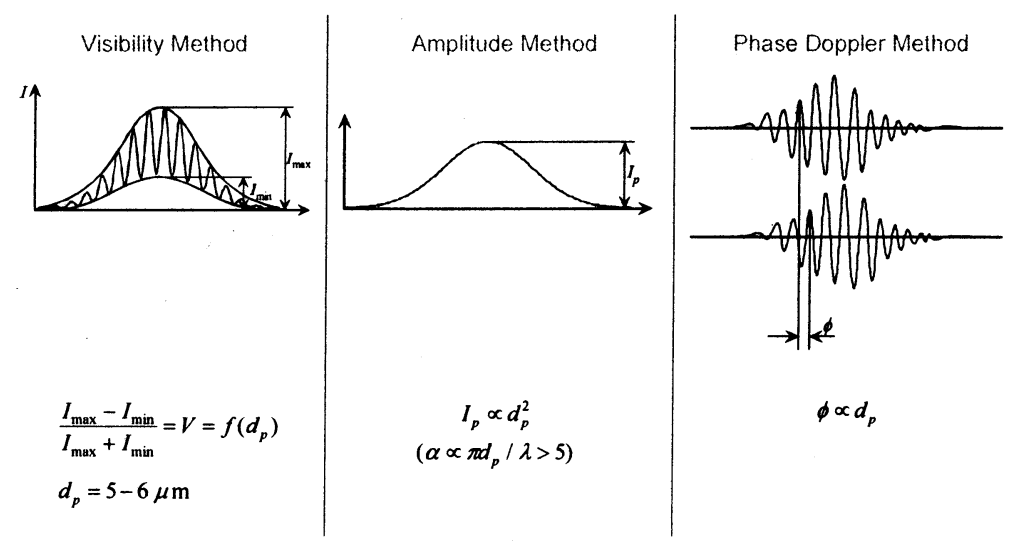

Fig. 2 Typical signals from LDV and principles for particle sizing 

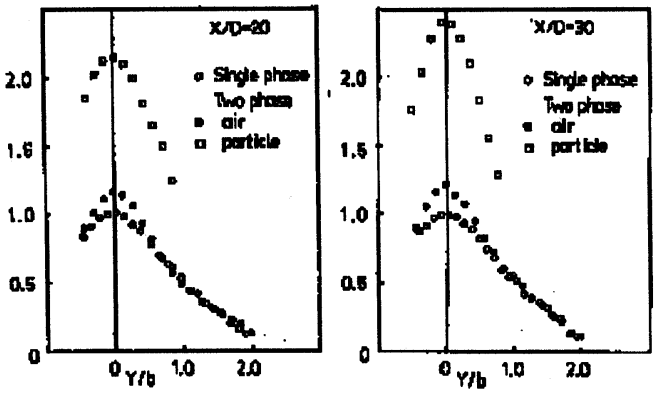

Fig. 3 Mean velocity profiles in jet flow

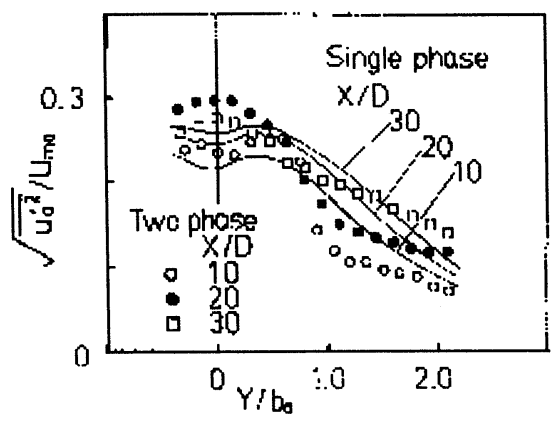

Fig. 4 Turbulence intensity profiles in jet flow

けば両相の速度および乱流諸量を測定できる，粒径測 定の程度は悪くても, トレーサ粒子(小径粒子) と分散 相の大径粒子との判別がつけられるような場合には, はん用の光学系をそのまま用いることができ, 比較的 簡単に二相流動場の測定が可能である. 信号処理系は 通常の LDVよりもやや複雑になっているが, 測定体 積のほぼ中央部を通過する粒子からの散乱光強度の差 によって, 気相のトレーサ粒子と, 大径のガラス粒子 とを弁別する ${ }^{(8)(9)}$. これにより分散相側の速度と連続 相である気相の速度の同時計測が可能となる.

噴流に関しては比較的多くの実験結果が報告されて いる．市販の LDV 単体では単に分散相の速度を計測 することは容易であるが, 気相の乱れの測定を行うこ とは難しい. それぞれの研究者ごとに前述のような信 号処理の工夫をこらしている. Modarressら (10) は2 波長 LDV を用いて気相と分散相との信号を分離して いる.

著者らの行った噴流での結果(9) をまとめて示す. これらは十分発達した円管から重量混合比 0.3 で鉛直 下方に流れる場についての測定結果である. 図 3 は流 れ方向の平均速度分布である. 重力方向に流れる下降 流であるために，気相より粒子が先行しているのがわ かる.また，二相時の気相速度は粒子により単相時に

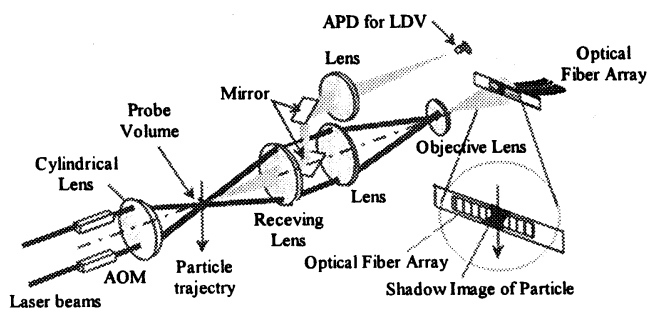

Fig. 5 Optical arrangement of Shadow Doppler Velocimetry

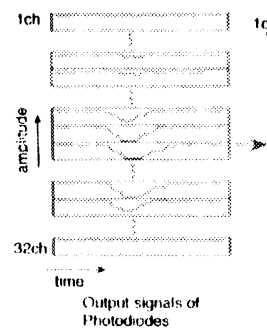

(a)

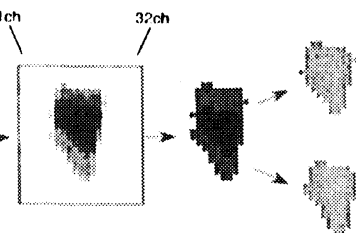

finconstructert Preuto lmay

(b)

(c)

(d)
Fig. 6 Signal processing for shadow image

比べ加速されているのが示されている.図 4 には流れ 方向と半径方向の気相の乱れ強さの分布を示す. せん 断が最も強い半值幅付近で大きく乱れが減少してい る.これらの粒子による乱流の変調が定量的にとらえ られた結果は, 二相乱流の数值モデルの構築に多大の 寄与をした。

\section{3. 投影法レーザ流速計 (非球形粒子計測)}

工業上現れる固気二相流はほとんどの場合, 非球形 粒子群であるが, それらの流れに対する計測法の一つ として,レーザ流速計の光学系を基本とした非球形粒 子の計測システムについて解説する.このほかにも回 折光強度による等価直径の計測法がある(11).ここで は, 粒子の二次元的な形状をも測定する投影法レーザ 流速計 (Shadow Doppler Velocimetry：SDV)につい て述べる。

投影法の基本的な原理と構成に関して, 図 5 に光学 系の概略図を示す ${ }^{(12)}$. 送光にははん用の 2 ビーム LDV を用い, 2 組の独立した受光系で速度と粒径測定 を行う．粒子の速度は，フォトダイオード(APD)で受 光したドップラー信号から FFT 法で算出した。粒径 測定の受光系には, 32 チャネルの並列出力をもつリニ アフォトダイオードアレイが取付けられており，粒子 が測定体積に進入すると, 結像面上に粒子の二次元的 な影が投影される。 

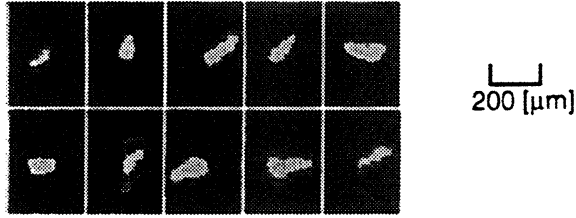

Fig. 7 Example of measured particle shape
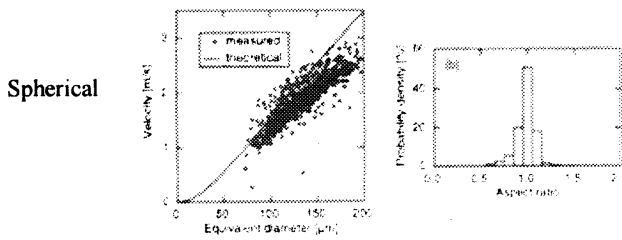

Non-Spherical
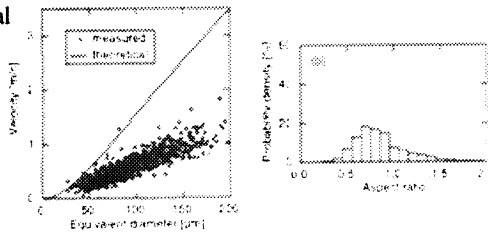

Fig. 8 Terminal velocity of spherical and non-spherical particles and their attitudes

図 6 に示されるようにセンサの瞬時の出力は, 粒子 の水平方向の一次元像に対応するので，速度情報を用 いて信号を時系列に追えば粒子の二次元形状を再構成 できる，信号処理において，記録には 32 チャネル，8 bit トランジェントレコーダを用い, データはパーソ ナルコンピュータに転送後, ソフトウェア上で処理を 行った。なお, 実際の像面積の計算は, 各粒子のデー タを二つのしきい値で 3 值化(濃い影, 薄い影および 影なし)したのちに計算される. 図 7 にステンレス粒 子に対する測定例を示した。その飛行姿勢も含めて計 測されているのがわかる，図 8 は静止䨌囲気中を自然 落下する球形ポリエチレン粒子と非球形の銅粒子の速 度とその際のアスペクト比を示す. 球形粒子では, 落 下終端速度で表される理論值とほぼ等しい值を有する のに対して, 非球形の粒子ではそれより著しく小さな 值を示している.そして水平方向の長さを分母にした アスペクト比も 0.7 付近にピークを有し，抵抗が大き くなるようにして落下する様子がとらえられている.

\section{4. 固液二相流中のラグラジアン計測 ${ }^{(13)(14)}$}

粒子画像流速計 (PIV) は面的な流れ場の計測が可能 で，現在でははん用の計測器として広く使用されるに 至っている. 著者らも, PIVの開発の初期の段階か ら, 種々の工夫を加えてきた. 現在では常識的に使わ

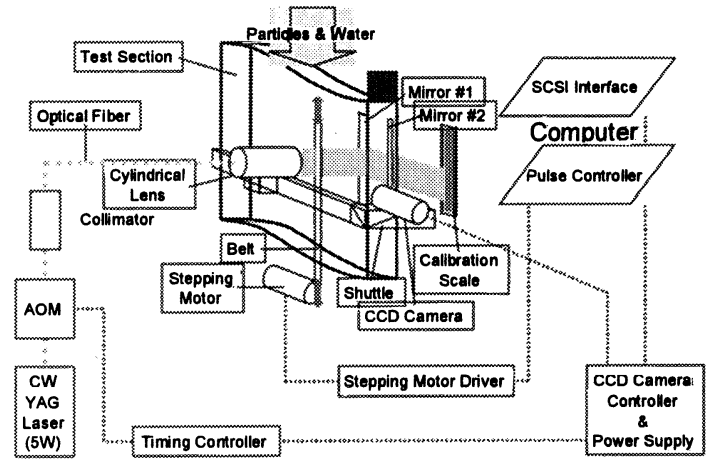

Fig. 9 Lagrangian PIV system for channel flow

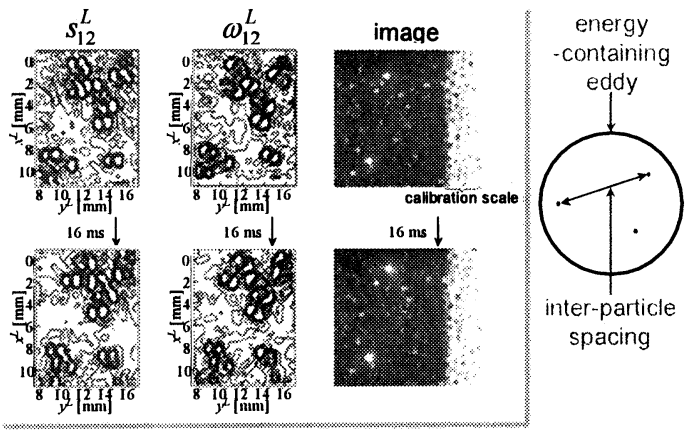

Fig. 10 Strain and vorticity in solid-liquid two-phase turbulent flow

れている CCD カメラを使い,オンラインで信号処理 することである. 初期の PIV は写真フィルムを使い, その処理は多大な時間を要していた時代である. そこ

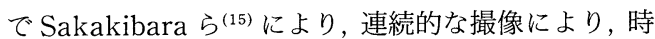
系列の面的な流れ場の計測を行えるようになった。こ の当時, 従来のPIVと区別するためにDPIV (Digital-PIV) と呼んでいた。もちろん，この手法は分散相 の形状まで認識でき, 固液二相乱流への適応に展開し た.

図 9 に固液二相流の計測に用いた DPIV システム の概略を示す. CCD カメラと光源はシャトルに固定 されており，上下移動する。これは後述するラグラジ アン計測の場合に利用する。トレーサ粒子として 10 $\mu \mathrm{m}$ 高密度ポリエチレン粒子(比重 0.96 )を懸濁した流 動場の $X-Y$ 面上に, レーザライトシートを照射し, 流動場の画像を CCD カメラに録画する、録画した映 像を 1 ビデオフレームずつコンピュータ中の画像取込 装置に格納する. 撮影した 2 画像間の局所的な濃度分 布パターンを相互相関係数によりマッチングさせて, 分散粒子およびトレーサ粒子の速度を求める。分散粒 


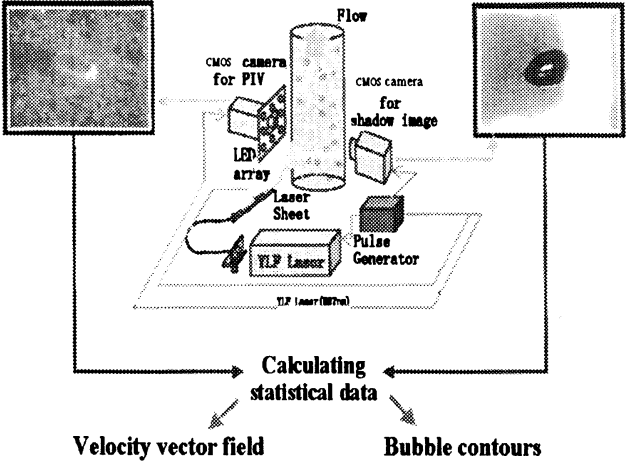

Fig. 11 Measuring system for two-phase flow using fluorescence tracer particles (left side picture) and Show Imaging (right side), and high repetition YLF laser

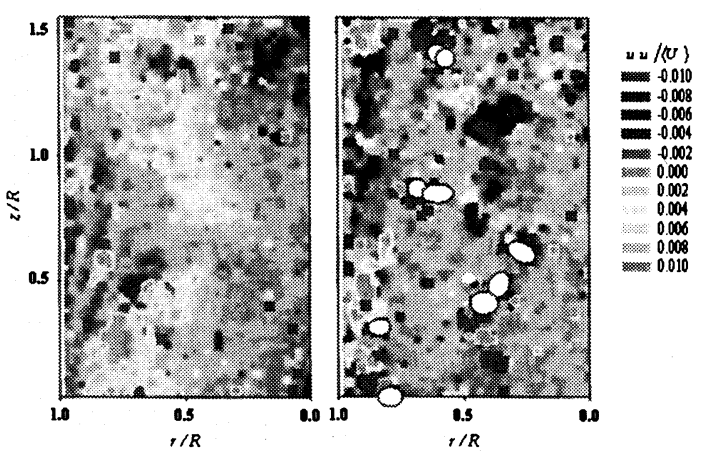

Fig 12 Instantaneous velocity correlation, $u_{z} u_{r}$, : left for single phase flow and right: in two-phase flow with $1-2 \mathrm{~mm}$ in diameter bubbles

子とトレーサ粒子の弁別は, 分散粒子の参照パターン を用いて行う。流動場は鉛直チャネル流で，流体には 水を用いる.チャネル幅を用いたレイノルズ数を 5700 とし, 試供粒子には $450 \mu \mathrm{m}$ ガラス粒子 $\left(R e_{p}=\right.$ 30)ほか 4 種類の粒子を用いる. 粒子および流体の速 度の計測にはPIV を使用する。

図 10 は測定結果の一例で, ラグラジアン座標から みた粒子群周りの変動速度のひずみ度 $S$ と渦度 $\omega$ の 瞬時の分布が示されており, 粒子間距離が短くなると 粒子間に大きなひずみが生じていることが明確に示さ れている。

\section{5. 蛍光粒子を用いた気泡流の計測(16) (18)}

刻々と変化する気泡形状とその周囲流体の相互作用 の解析には, 多点同時計測が可能である粒子画像流速
計は非常に有効な手段ではあるが，トレーサ粒子に比 べて 1000 倍以上の径を有する気泡を含む流れでは， 気液界面の存在により,さまざまな方向に屈折するレ 一ザ光の強度がトレーサ粒子の反射光に比べて非常に 大きいため, CCD の飽和を引き起こし, 気泡近傍のト レーサ粒子像の認識が困難となる。そこで, LIF (Laser-Induced Fluorescence)を応用することによ りこの問題を解決し, 図 11 にこのシステムの概略を 示す.

可視化用トレーサとして MMA（メタクリル酸メチ ル)にローダミン B を混入させた蛍光粒子(比重 1.02 , 粒径 3〜 $5 \mu \mathrm{m}$ ) を用い, 反射光をカットするカラーフ イルタを装着した CCD カメラで蛍光粒子の蛍光のみ を撮影する。これによって気泡とトレーサ粒子を画像 上で分離することが容易となり，気泡のごく近傍にお いてもトレーサ粒子の撮影が可能となる，一方，気泡 の形状測定については赤外線投影形状測定法 (Infrared Shadow Technique)を用いる。これは対象とす る物体に光源から赤外光を照射し，物体に対して光源 と対面に置かれた撮像センサによりその影を撮影する ことで物体の形状を認識する方法である。

図 12 に示す計測システムには $1284 \times 1024$ pixels の解像度で $500 \mathrm{~Hz}$ まで撮像可能な CMOS の高速度 ディジタルカメラを用いて，時系列の PIV 計測が可 能となっている、レーザシート光および撮影される画 像の屈折によるひずみを極力抑えるために FEP (fluorinated ethylene propylene copolymer)を用い て円管直径 $44 \mathrm{~mm}$ を上昇する流れを対象としてい る.レイノルズ数は約 10000 , ボイド率約 $1 \%$ 程度で, 上昇気泡流の流動計測を行った結果よりレイノズル応 力の空間分布を示したもので，単相時には管壁近くに おいて大きな正の值を有する部分が存在するのに対し て, 気泡混入時ではその值が極端に小さくなり分布し ていることがわかる.

\section{6. 干渉画像法による高密度液滴群の計測(19)}

高密度の噴霧などの粒径や速度の情報を得ること は，噴霧燃焼などの高効率化など極めて重要な問題で ある．従来から粒径と速度の同時測定に関しては位相 ドップラー法などが確立されているが，点計測であり， 瞬時の面的な情報を得ることができない.そこで, 著 者らの研究グループでは, 干渉画像法による新しい手 法を開発した。

図 13 では,レーザシート光の中の球形の液滴から の散乱光を集光すると焦点面には二つの点が観測され る。これを噴霧群に適応したものが図 14 に示す可視 


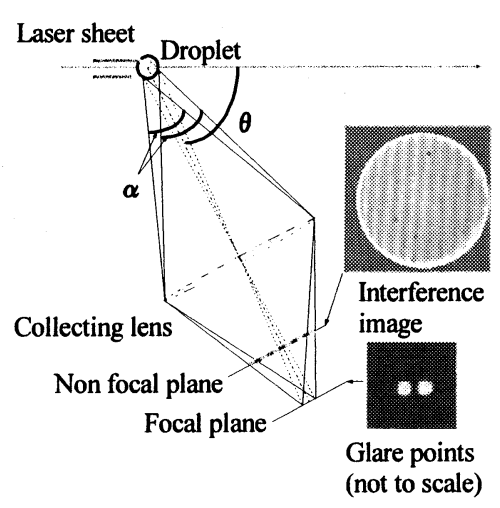

Fig. 13 Basic configuration of the interferometric laser imaging technique
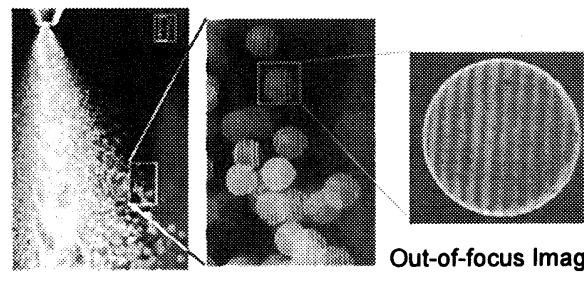

Out-of-focus Image

\section{DELAVEN Oil Burner Nozzle}

Fig. 14 Example of interferometeric image of spray
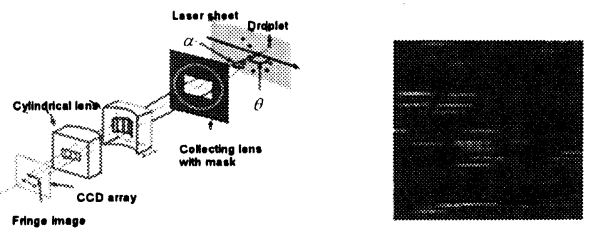

Fig. 15 Details of the receiving optics for compression with cylindrical lenses, and an example of measured interferometric image with compression lenses

化画像である．焦点からはずれた画像はあたかもピン ぼけのように見えるがさらに拡大してみると，そこに 干渉じまが観察される。これは, 液滴の表面反射と内 部屈折の光路差に基づくもので，この干渉じまの数が 粒径に対応している.しかしながら, 高密度の噴霧で は画像が重なり合い，それぞれを同定することは難し い.そこで，この画像を一定方向だけに圧縮すると， 図 15 に示すような画像に変換される.さらに 2 枚の 画像から，それぞれの移動量から速度が評価される。 計測システムとしては, 比較的高出力 $(100 \mathrm{~mJ} / \mathrm{pulse})$ の YAG(532 nm) を用いて, 撮像装置は $1000 \times 1000$ pixelsの高解像度のディジタルカメラを設置してい

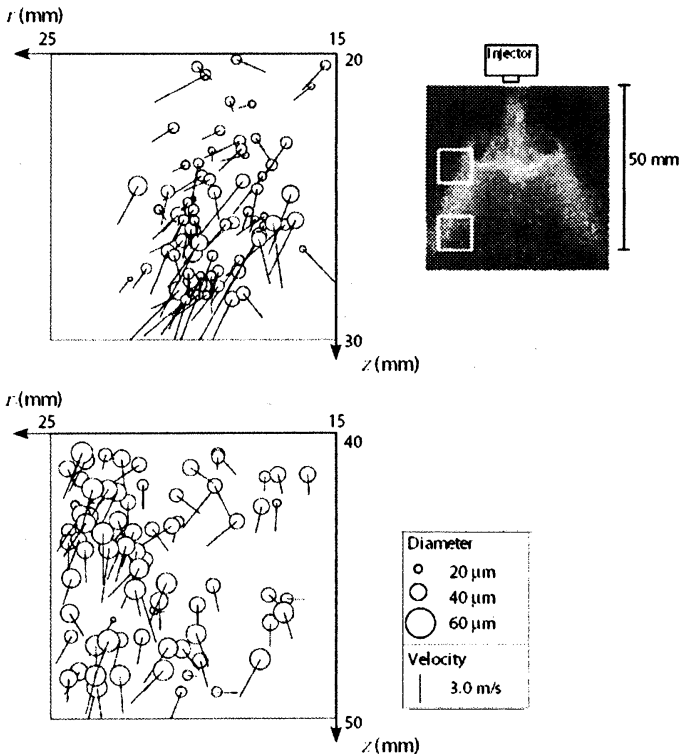

Fig. 16 Examples of the measured results of instantaneous droplet size and velocity distribution at $z=$ $25 \mathrm{~mm}, 45 \mathrm{~mm}$ of $r=20 \mathrm{~mm}$ from the nozzle at $t$ $=4.2 \mathrm{~ms}$ after the start of injection

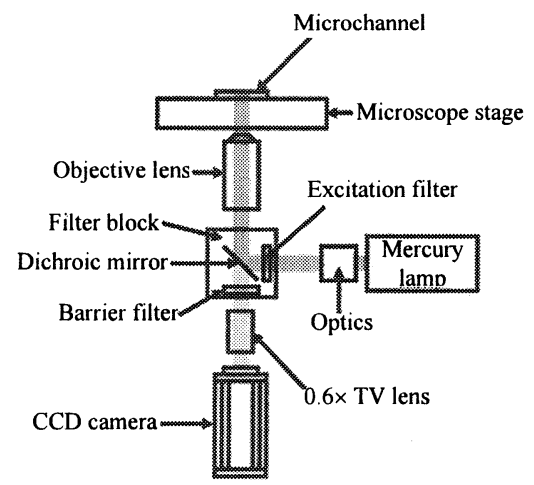

Fig. 17 Schematic of the measurement system using inverted epi-fluorescent microscope

る.図 16 は間欠燃料噴射ノズルからの液滴の速度と 粒径の大きさを測定した結果の一例で, 噴射後 1.2 $\mathrm{ms}$ 後の粒径, 速度の瞬時の空間分布である. 図 16 中 に示されるように下流域でより大径の液滴が多く存在 していることが示されている.

\section{7. サブミクロン粒子を用いたゼータ電位の評価 ${ }^{(20)}$}

近年, 微細加工技術の進展に伴い, 幅数 $\mu \mathrm{m}$ から数 百 $\mu \mathrm{m}$ の流路の作製が実現されてきた。マイクロ流路 内の流れの大きな特徴は, 表面積-体積比が大となる 


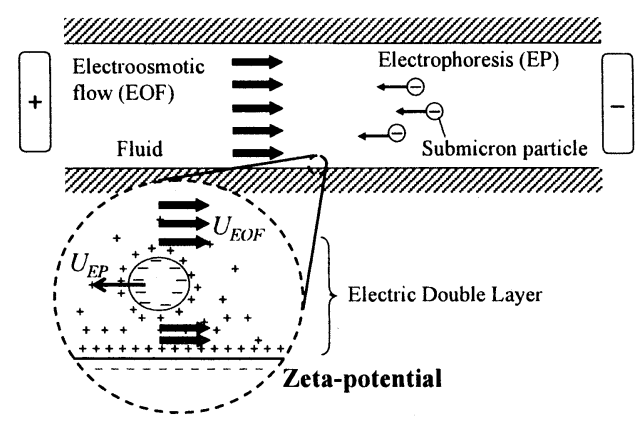

Fig. 18 Schematic of electroosmotic flow and electrophoresis

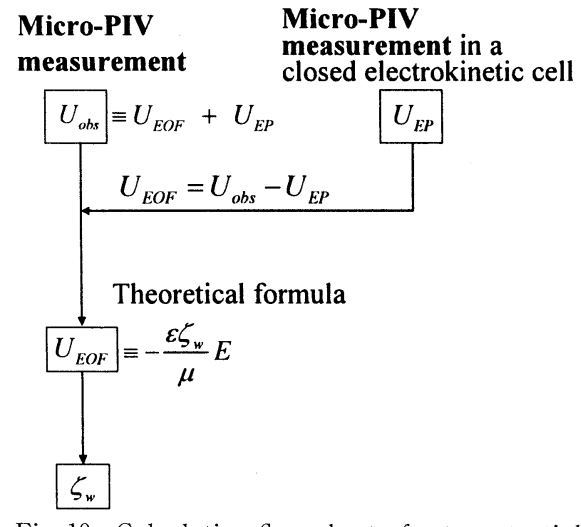

Fig. 19 Calculation flow chart of zeta-potential

ことで, $\mathrm{m}$ オーダ以上での流体では埋もれがちな流路 壁面の電気的性質 (ゼー夕電位に起因) が顕在化し, 電 界を印加することで流動が生じることにある.この流 れは電気浸透流と呼ばれ，その速度はゼー夕電位の大 きさに低存する。そのため, 従来からゼー夕電位の計 測法の確立が望まれてきた。

著者らの研究グループでは，流体中にサブミクロン 蛍光粒子を混入し, 図 17 に示すような蛍光顕微鏡と マイクロ PIVを用いて, 速度計測結果からゼー夕電 位を評価する手法を提案した。マイクロ流路内に電界 を印加すると, 図 18 に示すように負に帯電した粒子 は電気泳動により正極へ移動し, 流体は栓流となって 負極へ駆動される。そのため, マイクロPIVによる 見掛けの粒子速度 $U_{o b s}$ は, 電気泳動速度 $U_{E P}$ と電気 浸透流速度 $U_{E O F}$ の合成速度となる.図 19 にゼー夕 電位を算出するまでのフローチャートを示す，電気泳 動速度は密閉セル内の粒子挙動を計測し理論的に解析 することで求められることから, 電気浸透流速度は見 掛けの粒子速度から電気泳動速度を差引くことで評価

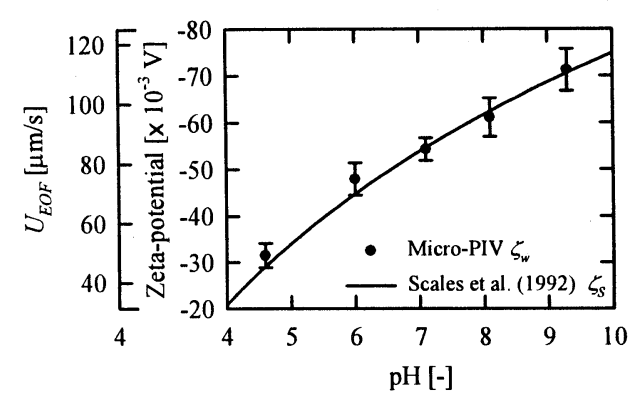

Fig. 20 Electroosmotic flow velocity and zeta-potential of silica glass microchannel with $95 \%$ confidence level in comparison to empirical equation versus $\mathrm{pH}$

できる.さらに, 流路壁面のゼー夕電位は, 電気浸透 流速度との線形関係から評価でき，その結果を図 20 に記した。なお，図 20 に併記した実線はゼー夕電位 の経験式であり，実験值と良好な一致を示しているこ とが明らかである。これらの計測は, マイクロ PIV の応用の一つであるが，ミクロンオーダでの分散系二 相流動がその電気化学的な性質に依存して発生してい ることに着目して計測システムを構築した例である.

\section{8. おわりに}

本研究展望では，著者らが過去に行ってきたレーザ を利用した流動計測について解説を行った．本文中に も少し述べたが，この種の計測にはこの 20 年のエレ クトロニクスの進展に負うところも少なくない. 特に パーソナルコンピュータの能力の向上は計測システム の中においてインテリジェント化に大きく貢献してき た。現在では一般的な流れ場・温度場であれば，だれ でも簡便に計測できるようになった。レーザ流速計や 粒子画像流速計などにおいても計測システムのパッケ ージ化が進み, 高度なデー夕処理までもが簡単に行う ことができる。これらは長年にわたり研究された要素 技術の蓄積の結果であるが，すぐ結果が得られる市販 のシステムを利用し，ある程度の成果が得られてしま うと，さらに本質的な現象を見いだそうとする努力を することが薄れてきたように思われる，混相流の流動 計測のみならず, 熱流動のかかわる計測には物理学・ 化学の原理原則を基礎とし，斬新なアイデアと融合し て，さらなる進展が行われる．「末知なる量を極限に 至るまでとらえたい」という研究者の探究心をもち続 け，ノウハウを蓄積した手作り装置で試行錯誤を繰返 すことで，新しい計測技術となって実用に供する基盤 技術となっていくものであると著者は信じている。こ 
の研究展望が熱流体の複雑な現象解明や設計要素とし ての重要な情報の収集の一助となれば幸いである.

\section{文献}

(1) Yeh, Y. and Cummings, H. Z., Localized Fluid Flow Measurements with an $\mathrm{He}-\mathrm{Ne}$ Laser Spectrometer, Applied Physics Letters, Vol. 4 (1964), pp. 176-178.

(2) Adrian, R. J., Scattering Particle Characteristics and Their Effect on Pulsed Laser Measurements of Fluid Flow; Speckle Velocimetry vs. Particle Image Velocimetry, Applied Optics, Vol. 23 (1984), pp. 16901691.

(3) Adrian, R. J., Particle-Imaging Techniques for Experimental Fluid Mechanics, Annual Reviews Fluid Mechanics, Vol. 23 (1991), pp. 261-304.

(4) Maeda, M., The Development of Flow Measurements Supported by the Progress of Novel Electronic Devices, Journal of Japan Society of Fluid Mechanics, Nagare, Vol. 25 (2006)-Vol. 26, (2007).

( 5 ) Hishida, K., Wanajou, T. and Maeda, M., Characteristics of Fluid Flow and Heat Transfer in Gas-Solids Multiphase Flow Behind a Step (Measurements of Turbulent Flow by Laser Velocimeter), Transactions of the Japan Society of Mechanical Engineers, Series B, Vol. 51, No. 467 (1985), pp. 2176-2183.

(6) Hishida, K., Takemoto, K. and Maeda, M., Turbulence Characteristics of Gas-Solids Two-Phase Confined Jet (Effect of Particle Density), Japanese Journal of Multiphase Flow, Vol. 1, No. 1 (1987), pp. 56-69.

(7) Hishida, K., Kobashi, K., Sanai, N. and Maeda, M., Simultaneous Measurement of Velocity and Size of Flowing Particles (Detection of Phase Shift of Doppler Signals by Fast Digital Processor), Transactions of the Japan Society of Mechanical Engineers, Series B, Vol. 55, No. 509 (1989), pp. 80-85.

(8) Maeda, M., Hishida, K., Matsumoto, C. and Ikai, S., Velocity Measurements of Dispersed and Continuous Phase in Suspension. Flow by a Modified LDV System, Transactions of the Japan Society of Mechanical Engineers Series B, Vol. 48, No. 425 (1982), pp. 88-96.

( 9 ) Hishida, K., Kaneko, K. and Maeda, M., Turbulence Structure of Gas-Solids Two-Phase Circular Jet, Transactions of the Japan Society of Mechanical Engineers Series B, Vol. 51, No. 467 (1985), pp. 2330-2337.

(10) Modaress, D., Tan, H. and Elgobashi, S., Two-Component LDA Measurement in Two-Phase Turbulent Jet, American Institute of Aeronautics and Astronautics Journal, Vol. 22 (1983), pp. 624-630.
(11) Morikita, H., Hishida, K. and Maeda, M., Simultaneous Measurements of Velocity and Equivalent Diameter of Nonspherical Particles Using Light Scattering Method, Transactions of the Japan Society of Mechanical Engineers, Series B, Vol. 59, No. 568 (1993), pp. 3749-3755.

(12) Hardalupas, Y., Hishida, K., Maeda, M., Morikita, H., Taylor, A. and Whitelaw, J. H., Shadow Doppler Technique for Sizing particles of Arbitrary Shape, Applied Optics, Vol. 33, No. 36 (1994), pp. 8417-8426.

(13) Sato, Y., Hayashi, I. and Hishida, K., Particle Dynamics in a Turbulent Channel Flow by Lagrangian Measurements, Transactions of the Japan Society of Mechanical Engineers, Series B, Vol.64, No. 619 (1998), pp. 701-708.

(14) Sato, Y., Fukuichi, U. and Hishida, K. Effect of InterParticle Spacing on Turbulence Modulation by Lagrangian PIV, International Journal of Heat and Fluid Flow, Vol. 21 (2000), pp. 554-561.

(15) Sakakibara, J., Hishida, K. and Maeda, M., Measurement of Thermally Stratified Pipe Flow Using ImageProcessing Techniques, Experiments in Fluids, Vol. 16 (1993), pp. 82-96.

(16) Tokuhiro, A., Maekawa, M., Iizuka, K., Hishida, K, and Maeda, M., Turbulent Flow Past a Bubble and an Ellipsoid Using Shadow-Image and PIV Techniques, International Journal of Multiphase Flow, Vol. 24 (1998), pp. 1383-1406.

(17) Fujiwara, A., Maekawa, M., Iizuka, K., Hishida, K. and Maeda, M., The Structure of Turbulent Fluid Flow Involving Gas Bubble (Measurement of the Fluid Flow in the Vicinity of Bubble by PIV), Transactions of the Japan Society of Mechanical Engineers, Series B, Vol. 64, No. 622 (1998), pp. 1697-1704.

(18) Sato, Y. and Hishida, K., Energy Transport Mechanisms in Particle-Laden Turbulent Water Channel Flow, Third International Symposium on Turbulence and Shear Flow Phenomena, Vol. 1 (2003), pp. 215220.

(19) Maeda, M., Kawaguchi, T. and Hishida, K., Novel Interferometric Measurement of Size and Velocity Distributions of Spherical Particles in Fluid Flows, Measurement Science and Technology, Vol. 11 (2000), L 13-L 18.

(20) Ichiyanagi, M., Sato, Y. and Hishida, K., Evaluation of Electroosmotic Velocity and Zeta-Potential in Microchannel Using Submicron Fluorescent Particles, Transactions of the Japan Society of Mechanical Engineers, Series B, Vol. 71, No. 709 (2005), pp. 2316-2323. 